\title{
Stability of Irrigation Canal Slopes Considering the Sea Level Rise and Dynamic Changes: Case Study El-Salam Canal, Egypt
}

\author{
Ismail Abd-Elaty ${ }^{1}$, Hazem Eldeeb ${ }^{1}{ }^{\mathbb{D}}$, Zuzana Vranayova ${ }^{2}$ and Martina Zelenakova ${ }^{3, *}$ \\ 1 Water and Water Structures Engineering Department, Faculty of Engineering, Zagazig University, \\ Zagazig 44519, Egypt; Eng_abdelaty2006@yahoo.com (I.A.-E.); Eng_heldeeb@yahoo.com (H.E.) \\ 2 Department of Architectural Engineering, Faculty of Civil Engineering, Technical University of Kosice, \\ 04200 Kosice, Slovakia; zuzana.vranayova@tuke.sk \\ 3 Department of Environmental Engineering, Faculty of Civil Engineering, Technical University of Kosice, \\ 04200 Kosice, Slovakia \\ * Correspondence: martina.zelenakova@tuke.sk; Tel.: +421-905-985-765
}

Received: 21 April 2019; Accepted: 14 May 2019; Published: 20 May 2019

\begin{abstract}
Stability of canals slopes are of paramount importance in engineering works due to its interaction with the infrastructure including roads networks and buildings. The failure of these slopes could cause human disaster, catastrophic environmental, and economic losses. The present study aims to investigate the stability of canals slopes considering the climate changes through sea level rise, fluctuation of groundwater level and the seismic actions. The study was simulated on the North Eastern part of Nile Delta aquifer, Egypt using the finite difference code of Visual MODFLOW. Moreover, the groundwater flow under the effect of sea level rise was investigated to study its effect on slope stability of El-Salam Canal, Egypt. Furthermore, the finite element program of Phase 2 was implemented, and safety factors were calculated using the shear strength reduction method (SSRM). The models are calibrated and verified through experimental work using permeability and seepage model. Moreover, the two models were applied on El-Salam Canal considering three scenarios to identify the safety factors including the effect of sea level rise (SLR), earthquake acceleration and a combination of the two scenarios. The results indicated that dynamic response values of the canal slope have different variation rules under near and far field earthquakes. Finally, the damage location and pattern of the slope failure are different in varying groundwater conditions.
\end{abstract}

Keywords: slope stability; sea level rise; climate changes; seismic actions; El-Salam Canal

\section{Introduction}

Failure of canal slopes are very dangerous problems in geotechnical engineering which lead to human, environmental, and economic problems. Many techniques are used for evaluating and analyzing slopes in order to invoke the remediation systems that overcome problems caused by slope failures. These slopes could be damaged under external loads, environmental conditions including changes in the groundwater table and canal stage, and many other reasons [1]. The failure surface in cohesion soils is deep while it is shallow in cohesionless soils, so the stabilizing systems were used to increase the safety of slope stability to avoid expected failure [2]. The slopes safety can be increased using drainage systems of surface and subsurface systems to modify the groundwater table, soil improvement techniques, and installing retaining structures such as concrete walls and sheet piles [3].

Sea level rise (SLR) is an important factor associated with global climate change [4]. Different sources of SLR measurements such as geologic indicators, tide gauges, and altimeters showed that the sea level has increased over the past 130 years [5]. Accurate measurements and 
prediction of sea level rise are complex due to being influenced, by other factors such as coastal subsidence, tectonic process and glacio-isostatic movements [4]. For the future, studies in 1996, 2001, and 2007 the Intergovernmental Panel on Climate Change (IPCC) [6-8] have estimated that the global sea to reach $0.94,0.88$, and $58 \mathrm{~cm}$ by 2100 . The SLR is estimated to be $3 \pm 0.4 \mathrm{~mm} /$ year with acceleration about $0.084 \pm 0.025 \mathrm{~mm} / \mathrm{y}^{2}$ [9].

A number of world aquifer will be affected by these changes. In Egypt, the studies also indicated that the Nile Delta quaternary aquifer will be affected by SLR. This costal aquifer is connected by the Mediterranean Sea in the north while the aquifer productivity thickness is extending between an upper semi-permeable clay layer and lower impermeable rocky layer [10]. This productivity aquifer is a semi-confined aquifer [11] and the quaternary layer thickness varies from $1000 \mathrm{~m}$ in the northern parts to $200 \mathrm{~m}$ in the southern parts RIGW (1992a) [12]. The aquifer base slope is about $4 \mathrm{~m} / \mathrm{km}$ to reach 40 times the average ground surface slope as presented in [13,14]. A number of studies were carried out to investigate the groundwater flow in the Nile Delta aquifer. Given the current conditions, the predicted impact of SLR by 25 and $50 \mathrm{~cm}$ on groundwater flow in the aquifer using 2D-FED model were simulated [15]. A numerical model was carried out using the FEFLOW model (a 3-D finite element variable density model) in Nile Delta aquifer under rising in sea level by 25,50 , and $100 \mathrm{~cm}$ [16]. The models results showed that the rise in sea level will effect on groundwater level and saltwater intrusion. Visual MODFLOW was used to simulate the effect of SLR in the northeastern Nile Delta, Egypt [17]; the study indicated that the salinity of groundwater abstraction will be increased from brackish water. A numerical study was developed [18] to simulate effects of climatic changes for increase in sea level by 25,50 , and $100 \mathrm{~cm}$ on the Nile delta aquifer using VISUAL MODFLOW. The results showed that the aquifer is sensitive for SLR and damaged large quantities of fresh water. The impact of SLR on design of subsurface drainage system in the Nile Delta, Egypt was studied [19], moreover the study indicated that climate change must be consider in the frame of the next water management strategies.

Evaluation of slope stability is an important part of geotechnical earthquake engineering due to its significant impact on infrastructure facilities such as buildings, bridges, roads, and lifelines and economic losses. Slopes failures are often observed following large earthquakes and the seismic slope stability methods can be divided into pseudo-static, sliding block, and stress-deformation [20]. Geo Studio software 2007 and 2-D finite element program of PLAXIS were used [21] to investigate the impact of earthquake shaking on stability safety and investigated the effect of embankment height and slopes on stability and liquefaction. The results showed that increasing embankment height and flattening could enhance stability and reduce the liquefaction zone. The seismic performance of slopes in pseudo-static designs with different safety factors was studied [22]. In this study the slope displacements obtained for different peak ground accelerations and safety factors are used to propose charts linking co-seismic slope displacements $(D)$, seismic coefficients $\left(K_{h}\right)$, and pseudo-static safety factors (FS), which are important parameters in pseudo-static approach. PLAXIS for modeling of bioreactor landfill was used [23]. The study showed that the factor of safety decreased as the solid waste was degraded with time, in both static and dynamic cases. The dynamic response and failure mode values were determined using finite element method for sandy slope subjected to fluctuation of groundwater conditions and the seismic forces actions [24]. The results indicated that these values have different variation rules.

This paper applies the finite element method, which is a fast and efficient design tool in modern engineering analysis, to evaluate the dynamic response of the slope when subjected simultaneously to seismic forces and variable groundwater conditions.

\section{Description of Study Area}

The current study area is a part of Nile Delta aquifer; this aquifer is one of the largest groundwater reservoirs [25] and this delta is one of the largest river deltas in worlds, covering an area of $22,000 \mathrm{~km}^{2}$ EGSA (1997) [26]. It is bounded by the Mediterranean Sea in North, the Suez Canal in East, the Ismailia 
Canal in South Eastern, and the Nubaria Canal in South Western. Also, it is located between the latitudes of $30^{\circ} 00^{\prime}$ and $31^{\circ} 45^{\prime} \mathrm{N}$, and the longitudes of $29^{\circ} 30^{\prime}$ and $32^{\circ} 30^{\prime}$ E MWRI [27].

The current study was applied on El-Salam Canal, which is located in the North East of Egypt, where it supplies water for the reclamation of new lands in that part of the country see Figure 1. This artificial canal provides water from the Nile river and drainage water pumped from the main drains which is mixed by the Nile water to supply the new of reclamation lands in this part of the country. These areas are originally parts of the sedimentary formation of the ancient Nile branches. The intake of canal starts at the right bank of Nile River branch of Damietta branch at $219 \mathrm{~km}$ and $3 \mathrm{~km}$ upstream the Faraskur dam and passes through five governorates from Damietta, Dakahliya, Sharkiya, and Port Said to North Sinai [28]. The canal total length is about $277 \mathrm{~km}$ and and supplies its water to an area of 62 hectares which is divided into two main parts; the first part at Western knowns as El-Salam Canal has $86 \mathrm{~km}$ and 22 hectare, and the second part has $191 \mathrm{~km}$ and 44 hectare at Eastern part of Sinai [29].

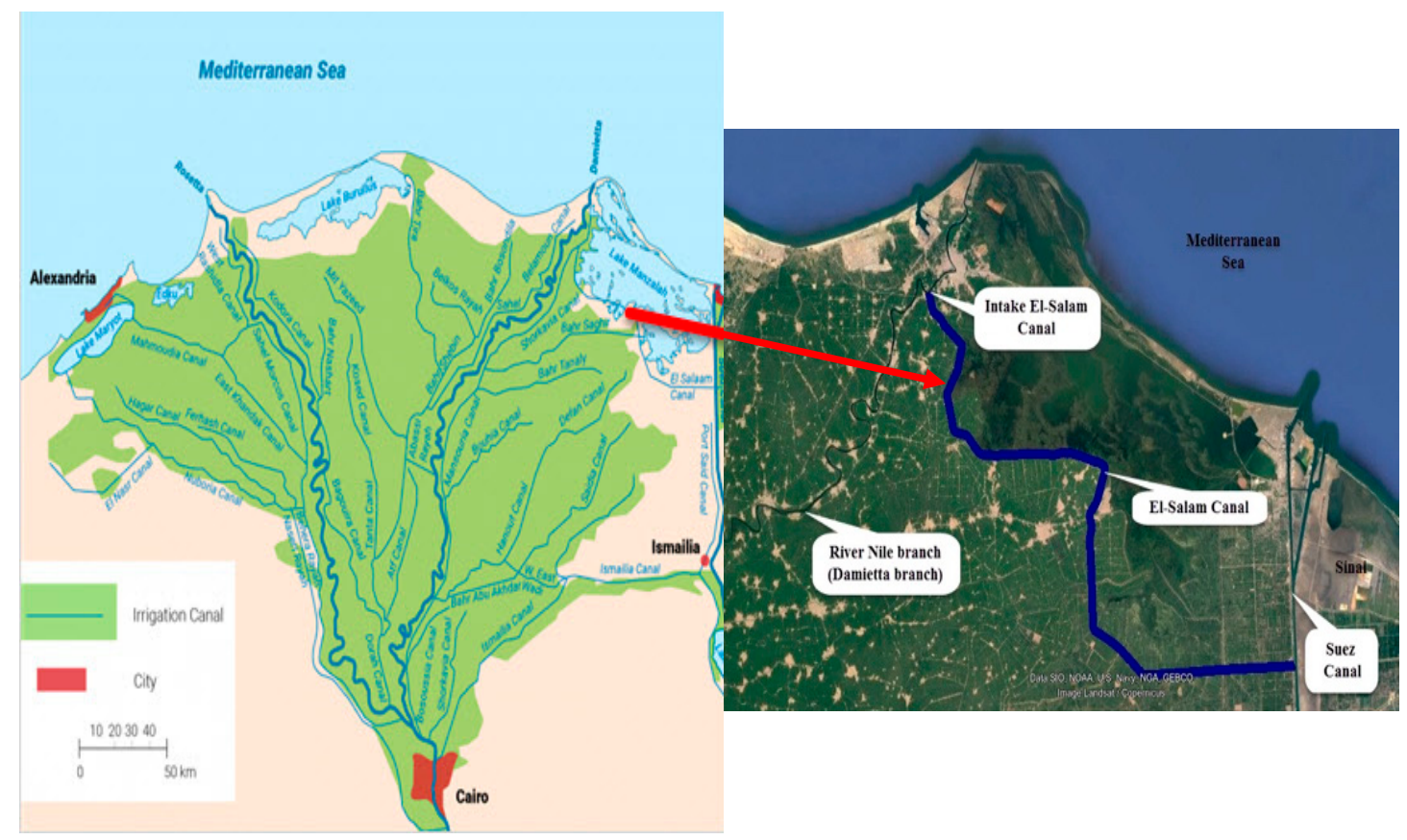

Figure 1. Location map of irrigation canals in the Nile Delta and El-Salam Canal path (Google Earth) (MWRI, 2005) [30].

The river Nile receives the back agricultural drainage water in Upper Egypt while this drainage water disposes to the Mediterranean Sea and North lakes in the Nile Delta. The collected drainage water is about 12 billion cubic meters (BCM) only about 5 BCM is currently being reused. Recently, the Egypt Government extended in newly reclaimed areas by using this water with a Nile water mix in a ratio of about 1:1 [31]. The water resources of the area west of Suez Canal and Sinai is supported by El-Salam Canal, the canals annual water supply is about 445 BCM milliard $\mathrm{m}^{3}$, about 2.11 BCM supplied from Nile water while 1.905 and 0.435 BCM from the Hadous drain and El-Serw drain [32]. The canal water salinity should not exceed $1250 \mathrm{mg} / \mathrm{L}$ [29].

In this study, VISUAL MODFLOW 2010 code is used to simulate groundwater flow SWI and assesses different scenarios for stability of canals slopes using the finite element software of Phase 2 in the North of Nile delta aquifer under SLR, an earthquake acceleration and a combination of the two scenarios. 


\section{Materials and Methods}

\subsection{Finite Difference Modelling}

The groundwater flow models fell into two stages. The first was a conceptual model to understand the physical problem, the second was translating the physical system into mathematical terms. The current study was carried out to simulate the groundwater flow using VISUAL MODFLOW 2010. It is a 3-D finite difference model of combined groundwater flow and solute transport models. This models application includes groundwater head, abstraction well optimization, aquifer storage and recovery, groundwater remediation, and saltwater intrusion. The partial-differential equation used in MODFLOW to simulate the groundwater flow is McDonald and Harbaugh (1988) [33].

$$
\frac{\partial}{\partial t}\left(K_{x x} \frac{\partial h}{\partial x}\right)+\frac{\partial}{\partial y}\left(K_{y y} \frac{\partial h}{\partial y}\right)+\frac{\partial}{\partial z}\left(K_{z z} \frac{\partial h}{\partial z}\right)+W=S_{s} \frac{\partial h}{\partial t}
$$

where: $K_{x x}, K_{y y}$, and $K_{z z}$ are the aquifer hydraulic conductivity in $x, y$, and $z$ respectively $\left(\mathrm{LT}^{-1}\right), h$ is the potentiometric head $(\mathrm{L}), W$ is volumetric flux per unit volume $\left(\mathrm{T}^{-1}\right), S_{S}$ is specific storage $\left(\mathrm{L}^{-1}\right)$, and $t$ is time $(\mathrm{T})$.

\subsubsection{Costal Aquifer Model of the Northeastern Nile Delta}

The finite difference code of Visual MODFLOW was applied to the North Eastern part of Nile Delta aquifer to simulate the groundwater flow for rising of sea level by 25 and $50 \mathrm{~cm}$ to investigate the impact of SLR on slope stability of the El-Salam Canal. The developed model was carried out using 135 rows and 127 columns for active and inactive cell using square cell dimension of $0.25 \mathrm{~km}^{2}$ as shown in Figure 2. The model thickness ranges from $700 \mathrm{~m}$ in the South to $950 \mathrm{~m}$ in the North including clay cap, this cap kept quaternary aquifer as a semi-confined aquifer. The model was digitized using eleven layers; the first was a clay cap with an average thickness of $50 \mathrm{~m}$, layers two to eleven were divided by equal thickness to represent the quaternary aquifer.

Figure 2 represents sections taken in X-direction from East at Suez Canal to West at Damietta branch, also in Y-direction. The model topography level (ground surface) varies from zero level to $1.00 \mathrm{~m}$ above mean sea level (MSL).

\subsubsection{Model Boundary Conditions and Hydraulic Parameters}

The study area was confined by four boundaries including a zero-specified head along shore line of Mediterranean Sea at the North and Suez Canal at East. The river package was assigned to El-Salam Canal starting from Nile flow in the West to end at Suez Canal in the East based on each reach conductance. The aquifer hydraulic parameters that were used in the simulated model were collected from experimental, field, and previous studied. The hydraulic conductivity of the clay layer ranged from 0.25 to $0.50 \mathrm{~m} /$ day while the specific yield and specific storage are 0.10 and $1 \times 10^{-5} \mathrm{~m}^{-1}$ respectively and the effective porosity between 50 to $60 \%$. Moreover, the quaternary aquifer hydraulic conductivity was between 50 to $150 \mathrm{~m} /$ day, the specific yield ranges from 0.15 to 0.20 , the specific storage is $1 \times 10^{-5} \mathrm{~m}^{-1}$ and the effective porosity ranges from 20 to $35 \%$. The recharge process plays a vital role on groundwater flow, the assign model recharge with ranges between zero to $0.80 \mathrm{~mm} / \mathrm{day}$. 


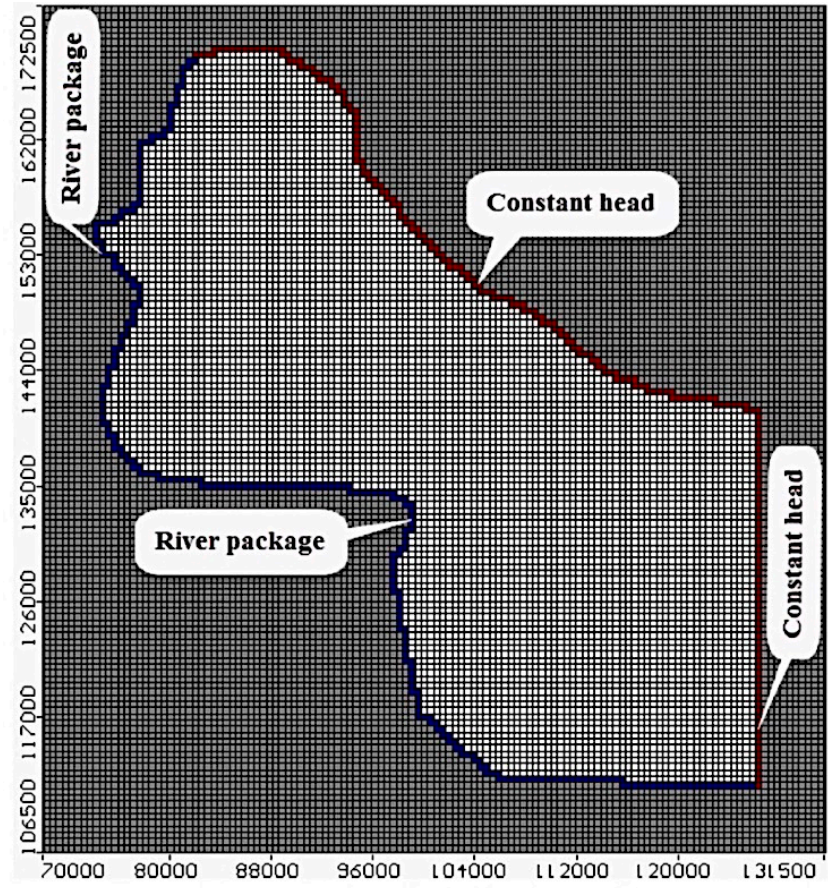

(a)

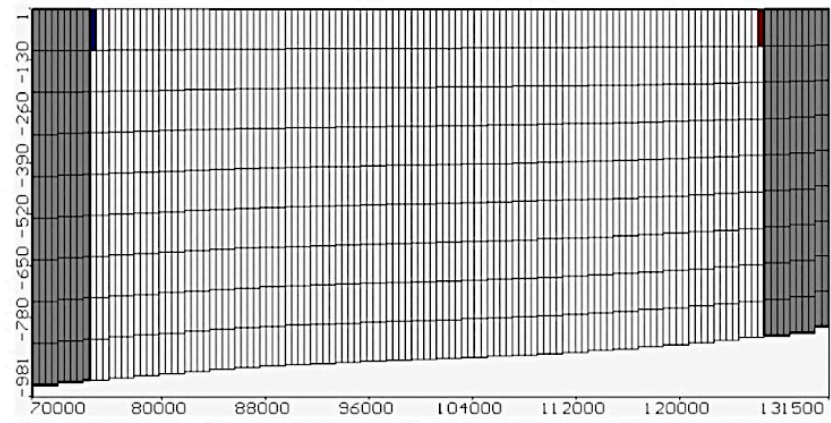

(c)

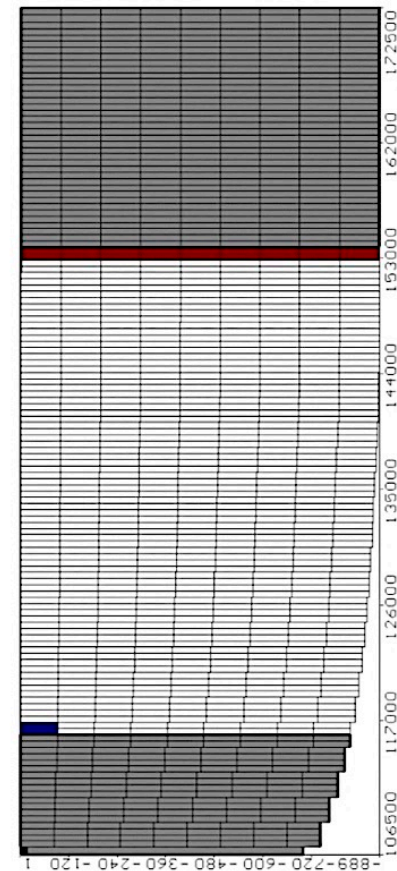

(b)

Figure 2. Model boundary conditions and cross section in (a) plan, (b) longitudinal section in X-direction and (c) transversal section in Y-direction.

\subsection{Finite Element Model}

The finite element software of Phase 2 was applied in this study to simulate the slope stability analysis. This software is a 2-D elasto-plastic finite element program for slope and excavation stability analyses, and it was used to calculate the stresses, displacements, slopes stability, and civil engineering problems. This software supports analysis of elastic and plastic materials but plastic material properties are defined only with isotropic properties. The factor of safety (FOS) in Phase 2 was calculated using the shear strength reduction method (SSRM) that simulated the problem in a just stable state of FOS equal one (Phase 2 version 8, 2011) [34]. Moreover, the failure criterion used in the slope analysis was Mohr-Coulomb failure criterion which was the better agreement with experiment results than the other theories of the slope analysis $[35,36]$. The selected failure criterion in the finite element model is Mohr-Coulomb criterion due to simply used with the finite element analysis. In addition, the model parameters were the meaningful soil shear strength parameters, soil modulus, Poisson's ratio, and the angle of dilation. Mohr-Coulomb is an elastic perfectly plastic model without stress softening or hardening. Figure 3 shows a 2-D graphical representation of the slope safety factor using Mohr-Coulomb failure criterion in conjunction with strength reduction method (SRT). The FOS using 
Mohr-Coulomb failure criterion in conjunction with the strength reduction technique is presented in the following equations:

$$
\begin{gathered}
I_{1}=\sigma_{x x}+\sigma_{y y}+\sigma_{z z} \\
J_{2}=\frac{1}{6}\left[\left(\sigma_{x x}-\sigma_{y y}\right)^{2}+\left(\sigma_{y y}-\sigma_{z z}\right)^{2}+\left(\sigma_{z z}-\sigma_{x x}\right)^{2}\right]+\tau_{x y}{ }^{2}+\tau_{y z}{ }^{2}+\tau_{z x}{ }^{2} \\
J_{3}=\left(\sigma_{x x}-\frac{I_{1}}{3}\right)\left(\sigma_{y y}-\frac{I_{1}}{3}\right)\left(\sigma_{z z}-\frac{I_{1}}{3}\right)+2 \tau_{x y} \tau_{y z} \tau_{z x}-\left(\sigma_{x x}-\frac{I_{1}}{3}\right) \tau_{y z}{ }^{2}-\left(\sigma_{y y}-\frac{I_{1}}{3}\right) \tau_{z x}{ }^{2}-\left(\sigma_{z z}-\frac{I_{1}}{3}\right) \tau_{x y}{ }^{2} \\
\theta=\frac{1}{3} \sin ^{-1}\left[-\frac{3 \sqrt{3} J_{3}}{2 J_{2}{ }^{1.50}}\right] \quad-\frac{\pi}{6}<\theta<\frac{\pi}{6} \\
S=\sqrt{J_{2}} \\
S_{\max }=\frac{\frac{I_{1}}{3} \sin \phi+c \cos \phi}{\cos \theta+\frac{\sin \theta \sin \phi}{\sqrt{3}}} \\
\text { Factor of safety(FOS })=\frac{S_{\max }}{S}
\end{gathered}
$$

where: $I_{1}$ are the principal stresses invariant $\left[\mathrm{F} \mathrm{L}^{-2}\right], J_{2}$ and $J_{3}$ are deviatoric stresses invariants $\left[\mathrm{F}^{2}\right.$ $\left.\mathrm{L}^{-4}\right], S$ is the deviator stress $\left[\mathrm{F} \mathrm{L}^{-2}\right], S_{\max }$ is the max deviator stress $\left[\mathrm{F} \mathrm{L}^{-2}\right], C$ is Cohesion $\left[\mathrm{F} \mathrm{L}^{-2}\right], \phi$ is Friction angle [degree], $\theta$ : is inclination angle [degree], $\tau$ is shear stress $\left[\mathrm{F} \mathrm{L}^{-2}\right.$ ], and $\sigma$ is the total stress $\left[\mathrm{F} \mathrm{L}^{-2}\right]$.

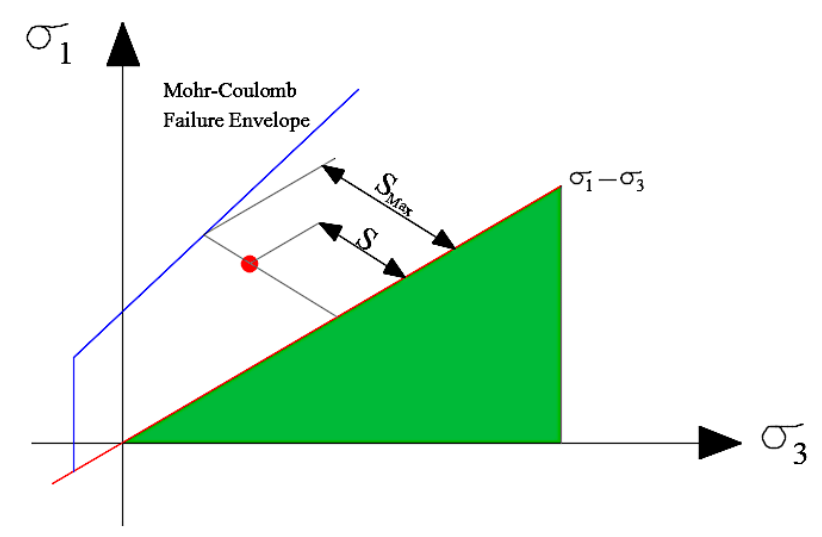

Figure 3. 2-D Graphical Representation of Mohr-Coulomb Criterion in Conjunction with shear strength reduction method (SSRM) Technique (Phase ${ }^{2}$ V.8, 2011) [34].

\section{El-Salam Canal Model}

Although Egypt is characterized by low seismicity, it has experienced damaging earthquake effects throughout its history. Figure 4 shows a revised catalog of earthquakes for the Eastern Mediterranean region during the period from $2200 \mathrm{BC}$ to $2009 \mathrm{AD}$, based on information from several international and local seismic catalogs. This catalog was processed through different steps, including the elimination of repetitions and the scale of unifying magnitude [37]. The two critical events affecting Cairo were Ms. 5.8 in 1847 [38] and Ms. 5.4, the Cairo earthquake in October 1992 [39,40]. The earthquake in Cairo is still one of the most painful events and is buried in memory of the Egyptians due to the loss and damage associated with it including; 561 deaths, 10,000 injured, and 3,000 families lost their homes [41].

The numerical model of phase 2 was applied to identify the stability factor of on El-Salam Canal slope under the impact of sea level rise and earthquake. Three scenarios were considered to investigate the FOS of canal side slope under the effect of SLR by $26.70 \mathrm{~cm}$ and $51.30 \mathrm{~cm}$ (Scenario one), increasing earthquake horizontal acceleration to $0.1 \mathrm{~g}$ and $0.2 \mathrm{~g}$ (Scenario two), and the combination of scenario one and two (Scenario three). The typical cross section of the canal is presented in Figure 5. This figure 
is based on the previous studies which applied on this slope starting with a general planning study performed by the Egyptian Ministry of Water Resources and Irrigation. Moreover, Figure 6 presented the soil profile using boreholes which carried out for El-Salam Canal from $8.800 \mathrm{~km}$ to $8.850 \mathrm{~km}$ [42].



Figure 4. Seismicity of Eastern Mediterranean region based on the compiled earthquake catalog (Badawy et al. 2016) [43].

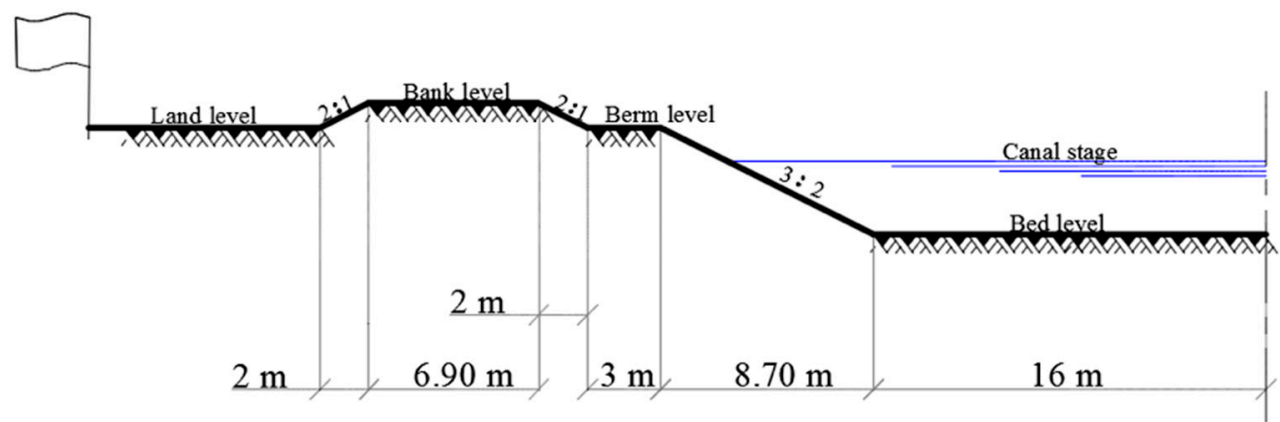

Figure 5. Schematic diagram of El-Salam Canal cross section Al-Ashaal et al. (1998) [42]. 


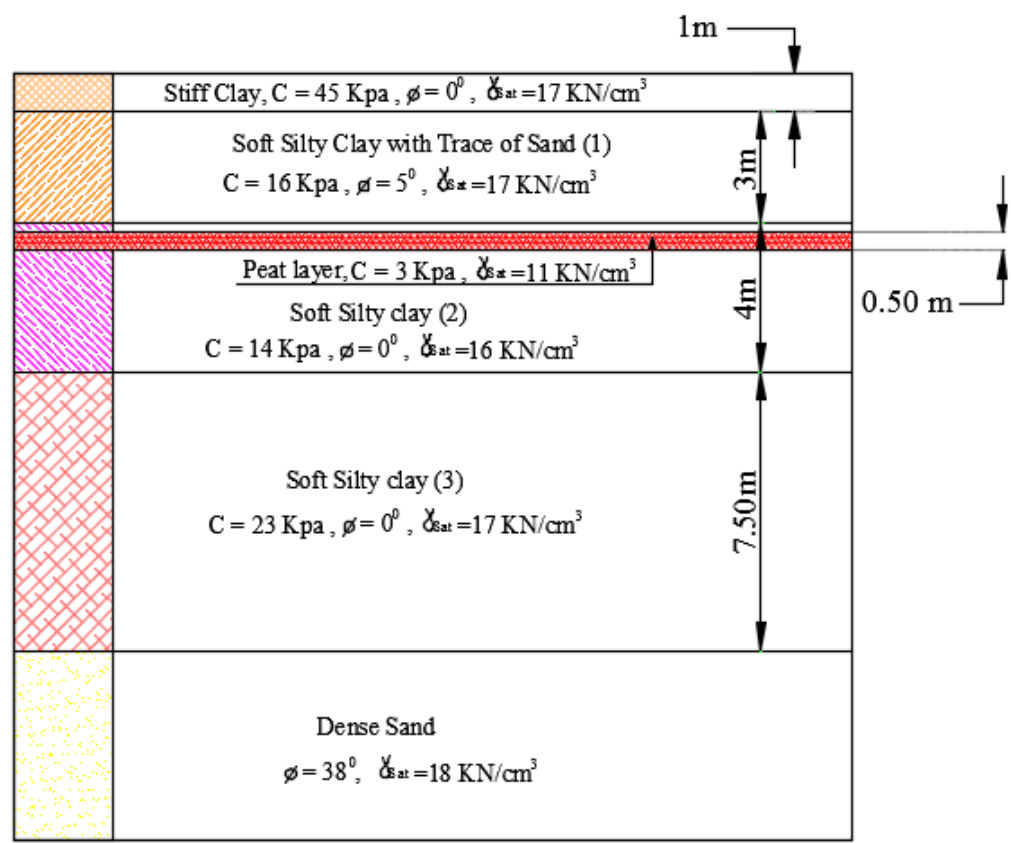

Figure 6. Stratification of slope soil (Al-Ashaal et al. 1998) [42].

\section{Results and Discussion}

\subsection{Calibration of Groundwater Flow Model}

The calibration process of groundwater flow model is the critical model step which comparing the calculated model heads with measured in field. This process was conducted before using of the developed model in the future prediction. The simulated model was calibrated by changing the aquifer hydraulic properties using trial and error to get the target of calibration by minimizing difference between the calculated and measured heads. The model was calibrated based on field data which measured by RIGW in 2008 and published by Morsy (2009) [44]. Figure 7 represents the difference between calculated and observed head in the study area for a number of 12 observations well. The residual range is between -0.022 and $0.004 \mathrm{~m}$ with root mean square (RMS) of $0.017 \mathrm{~m}$ while the normalization RMS is $7.042 \%$. The model calibration target was 10\% the difference between maximum and minimum head to be $0.03 \mathrm{~m}$ the results are greet satisfactory.

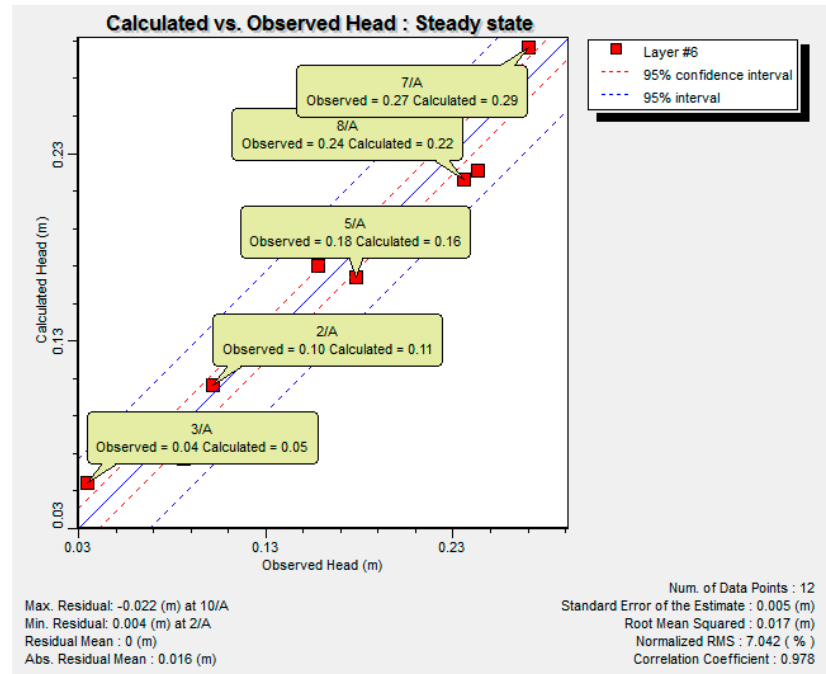

Figure 7. Calculated and observed head in study area. 
Figure 8 indicates that the groundwater head ranges from a zero value at the North to $0.30 \mathrm{~m}$ at the South. Also, the model flow direction is gradually from high head at the Southwestern where the Nile branch of Damietta and El-Salam Canal are located to supply the aquifer while the low head at the North. The groundwater velocity for the clay and quaternary layer are $2.70 \times 10^{-5}$ and $0.01 \mathrm{~m} / \mathrm{d}$ respectively. The model results indicate a great satisfactory between calculated heads compare with the field data; this gives much reality to predict the groundwater level in the future.

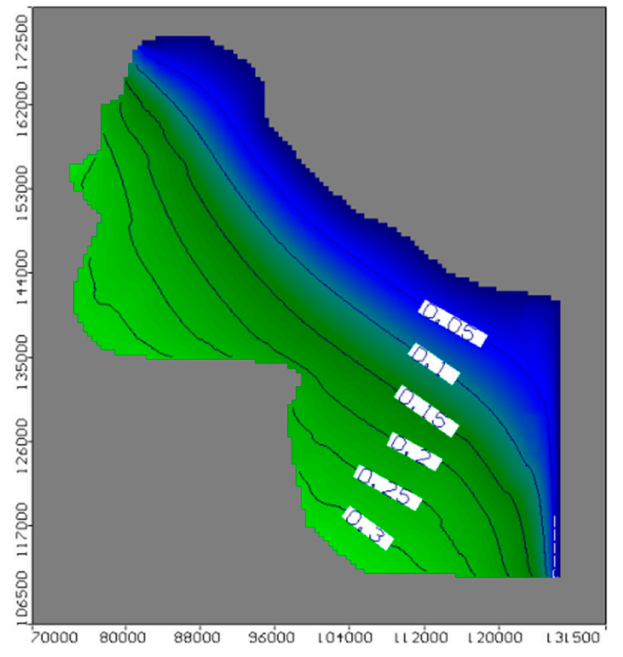

(a)

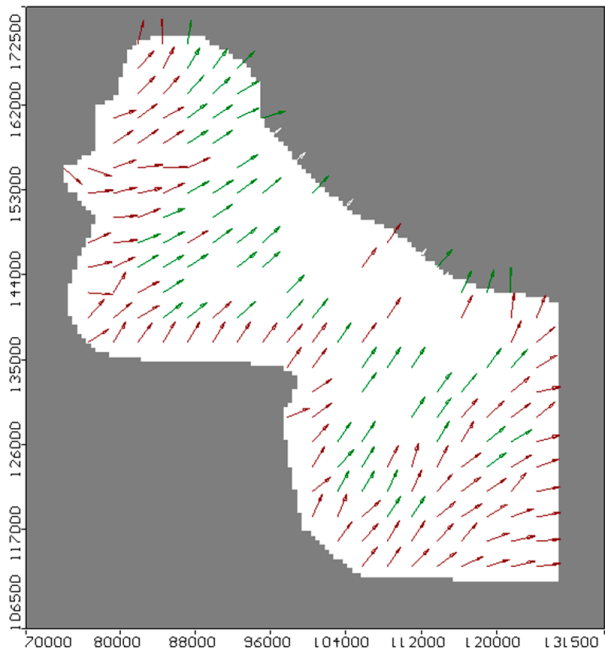

(b)

Head Equipotentials [m

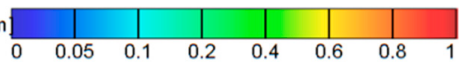

Figure 8. Arial view of the study area at base for (a) groundwater head and (b) velocity direction.

\subsection{Impact of Sea Level Rise on Groundwater Level at Project Area}

Based on Legeais et al. (2018) [9] estimation, the SLR was calculated for years 2060 and 2090 to be 26.70 and 51.30 respectively (referred to year 2000). Figure 9 presents the results of increase sea level by 26.70 and $51.30 \mathrm{~cm}$, it is clear that SLR leads to increase the aquifer piezometric head. Moreover, the maximum increase occurred along the shore line of Mediterranean Sea at the North and Suez Canal at East, and decreased gradually to West South.

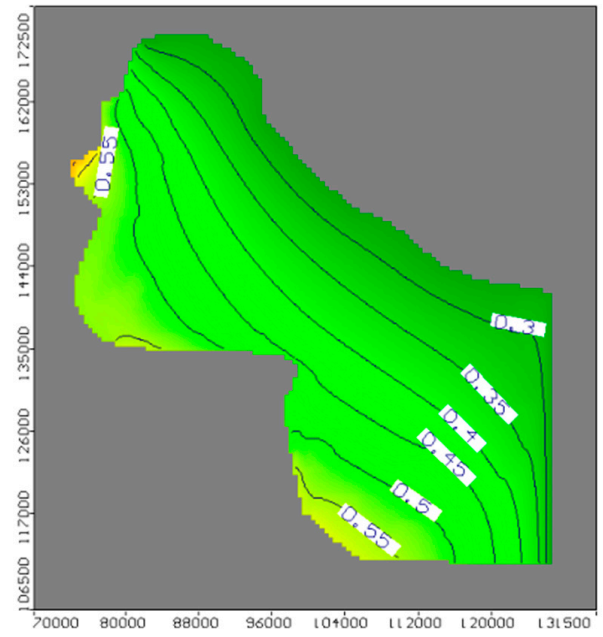

(a)

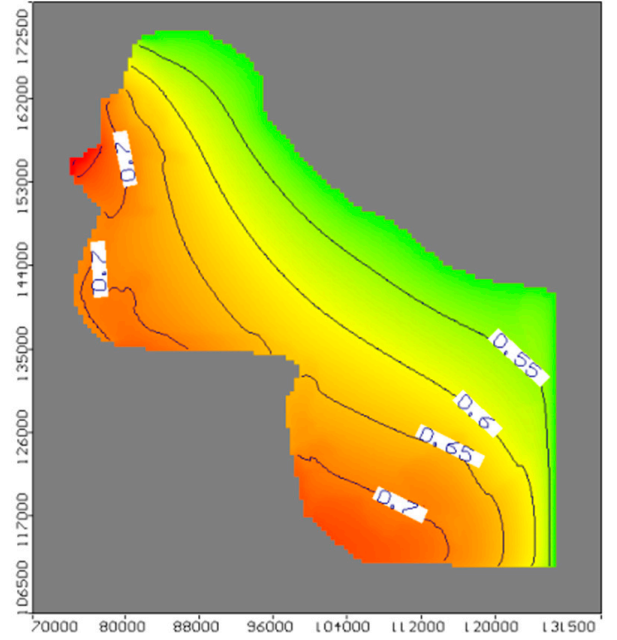

(b)

Head Equipotentials [m

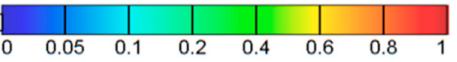

Figure 9. Arial view of groundwater level in study area at sea level rise (SLR) by (a) 26.70 and (b) $51.30 \mathrm{~cm}$. 


\subsection{Verification of Slope Stability Model Using Experimental Model}

The current stability model was calibrated using the experimental carried out by Al-Quamhawy (2016) [45]. This models dimensions were $100 \mathrm{~cm}$ length with $4 \mathrm{~cm}$ width, the right depth was $25 \mathrm{~cm}$ to represent the canal and the left depth is $50 \mathrm{~cm}$ to represent the embankment while the side slope ratio of $2 \mathrm{H}$ (horizontal) to $1 \mathrm{~V}$ (vertical). The laboratory methods were used to measure the model hydraulic parameter for the internal angle of friction ( $\varnothing$ ) and the soil porosity to be $30^{\circ}$ and $30 \%$ respectively while the hydraulic conductivity was calculated using Darcy's law under the steady state conditions to be $28.50 \mathrm{~m} /$ day. The model boundary conditions were assigned using the water depth ratio at embankment side equals 0.80 from total height and the canal water depth is zero. Figure 10a,b presents the failure wedge for numerical and experimental model, the figure prevailed that the failure wedge is near to the toe of slope. Furthermore, the piezometric line and water table show a good agreement between the experimental and numerical models, and the mean relative error was $8.77 \%$.

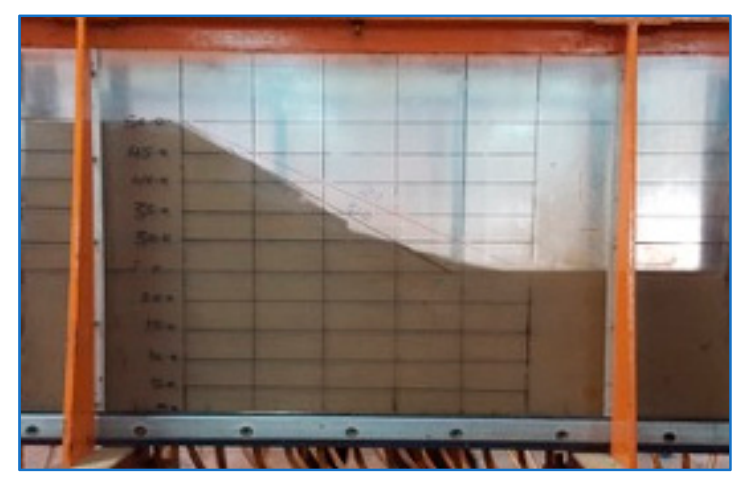

(a)

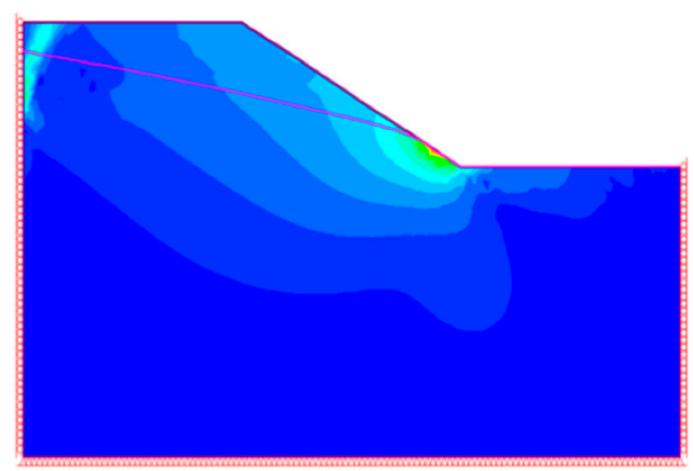

(b)

Figure 10. Side slope deformation (a) experimental model Al-Quamhawy (2016) [45] and (b) the current numerical model.

The model was developed to the case study of El-Salam Canal and used the hydraulic parameters from soil profile that are presented in Figure 6. The model boundary conditions were assigned based on the field data of groundwater head and the canal stage to be 3 and $2.95 \mathrm{~m}$ respectively from canal bed. Moreover, the piezometric lines packages were chosen to simulate the water table as shown in Figure 11. The deformations due to the pore water pressure and the effective stress could be calculated.

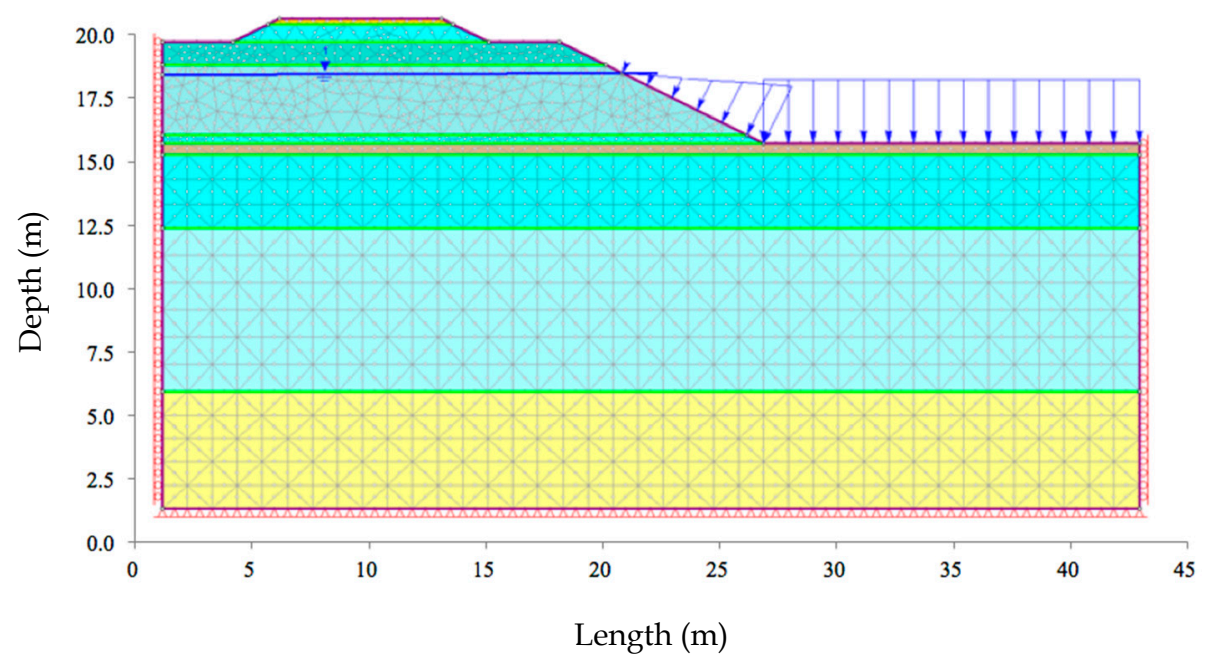

Figure 11. Water table modelling using piezometric line for base case $\left(\mathrm{H}_{\mathrm{C}}=3.0 \mathrm{~m}, \mathrm{Hs}=2.95 \mathrm{~m}\right)$. 
The failure in soil occurs when the actual shear stresses exceed the soil strength. The results of slope analysis using SRM technique were shown in Figure 12 which shows the shading contours of the maximum shear strain with the slope depth. The sliding surface passed through the peat layer because it is considered the weakest layer in the slope stratification. The calculated safety factor was reached 1.086. Thus, increasing the soil shear strength parameters for the soil cohesion and the internal angle of friction leads to increase the slope safety against shear failure. The maximum values of the embankment displacement were found to be 18.20, 24.30, and $42.16 \mathrm{~cm}$ for the horizontal, vertical, and total displacement respectively due to the slope own weight as shown in Figure 13.

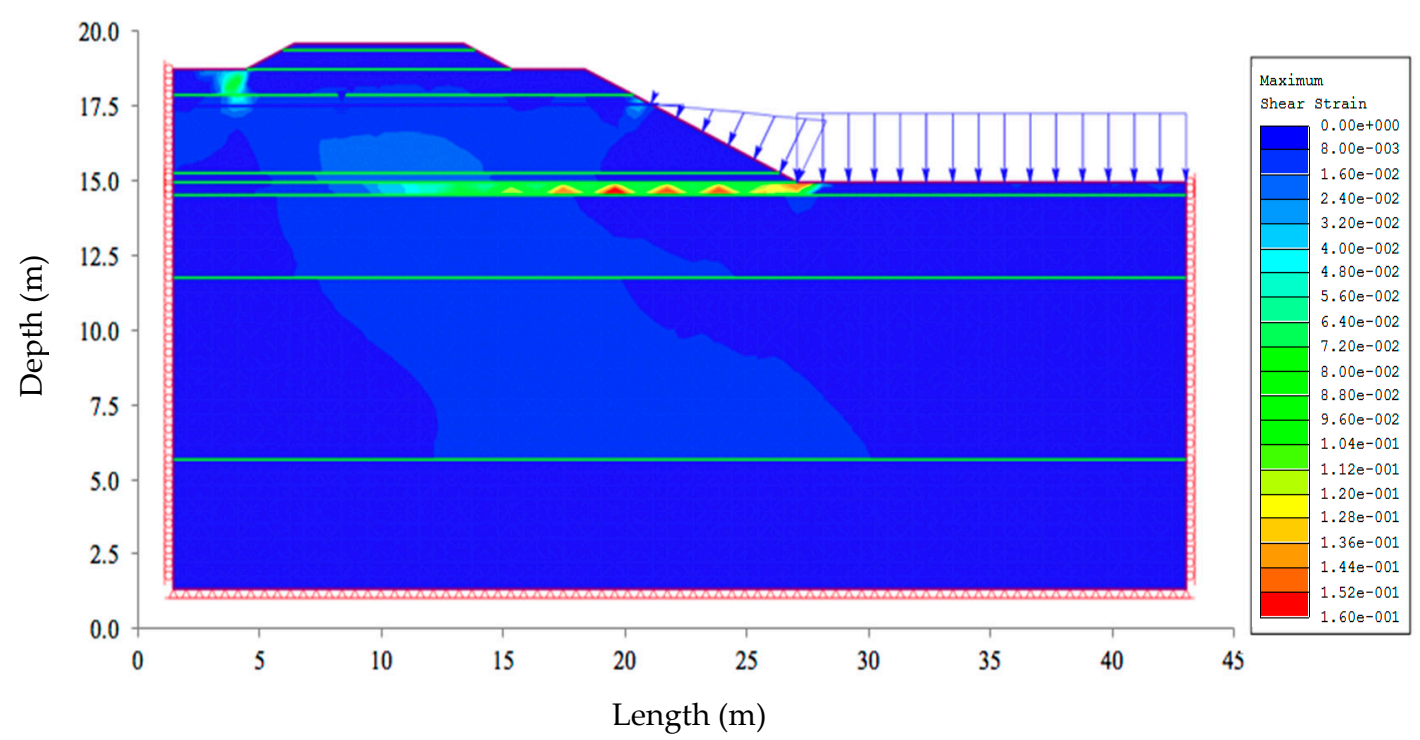

Figure 12. Colored contour shading of maximum shear strain (base case).

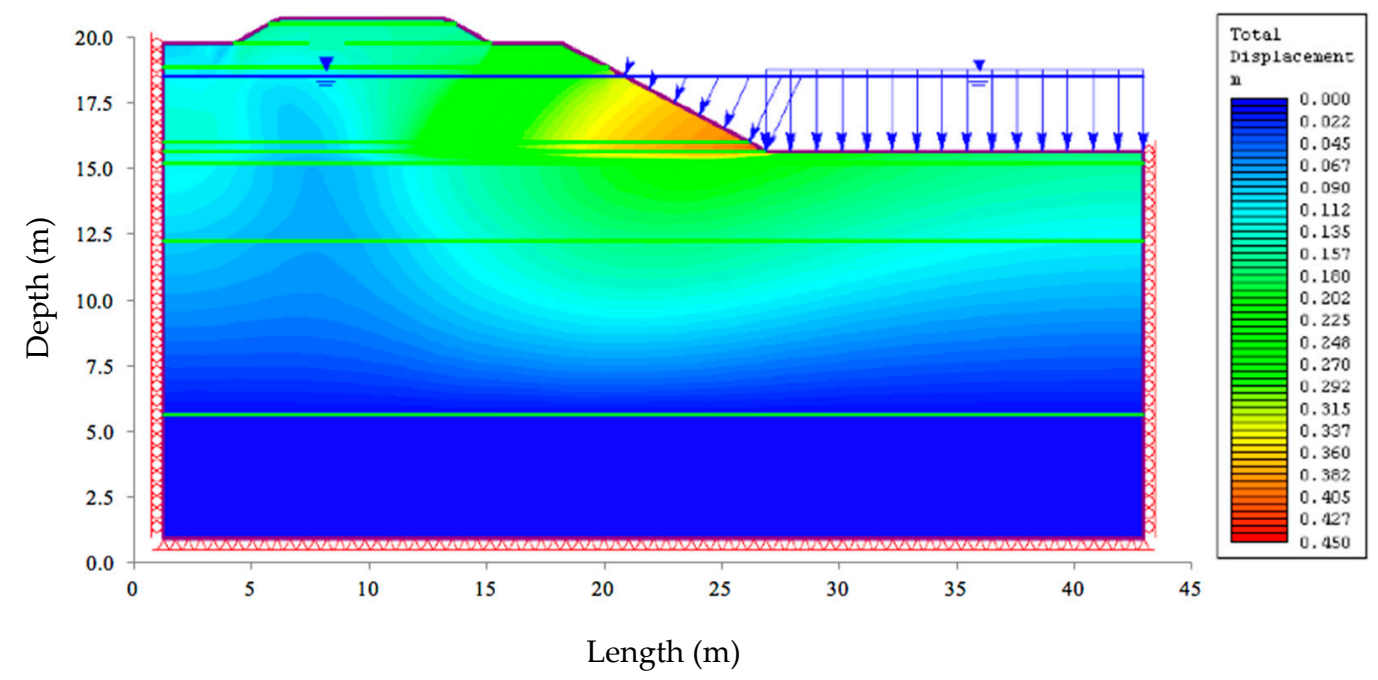

Figure 13. Colored contour shading of the total displacement (base case).

\subsection{Effect of Sea Level Rise on Factor of Safety of Canal Slope}

The effect of SLR on canal embankment was studied. The SLR was increased by 26.70 and $51.30 \mathrm{~cm}$, thus the groundwater level reached 0.60 and 0.70 from MSL. Figures 14 and 15 represent shear strain and total displacement distribution under the variation of SLR by 26.70 and $51.30 \mathrm{~cm}$. Moreover, the canal slope FOS reached 1.083 and 1.072 respectively comparing with original value. Furthermore, the results indicated that the maximum shear strain in the slope was concentrated with the peat layer region and increased with groundwater level increase. Figure 16 describes the decrease of canal slope 
FOS against sea level rise SLR. It is noticed that for SLR equals 26.70 and $51.30 \mathrm{~cm}$ the FOS decreases by $0.3 \%$ and $1.3 \%$ from the base case respectively.

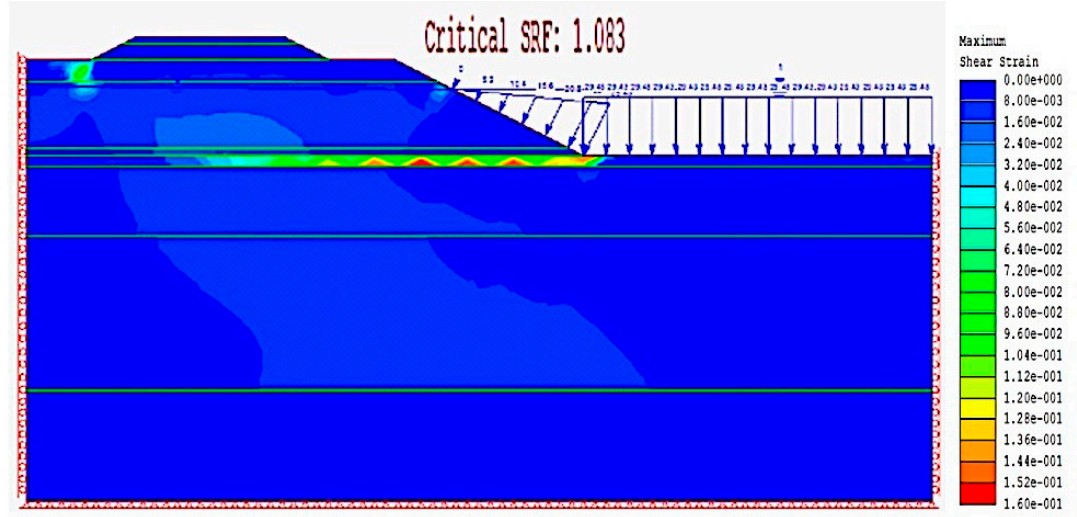

(a)

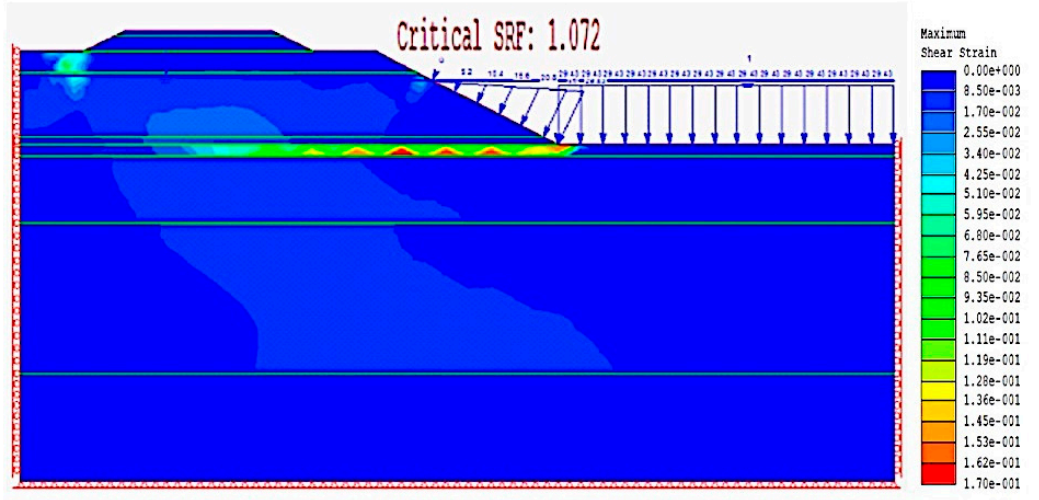

(b)

Figure 14. Colored contour shading of shear strain at SLR by (a) $26.70 \mathrm{~cm}$ and (b) $51.30 \mathrm{~cm}$. 


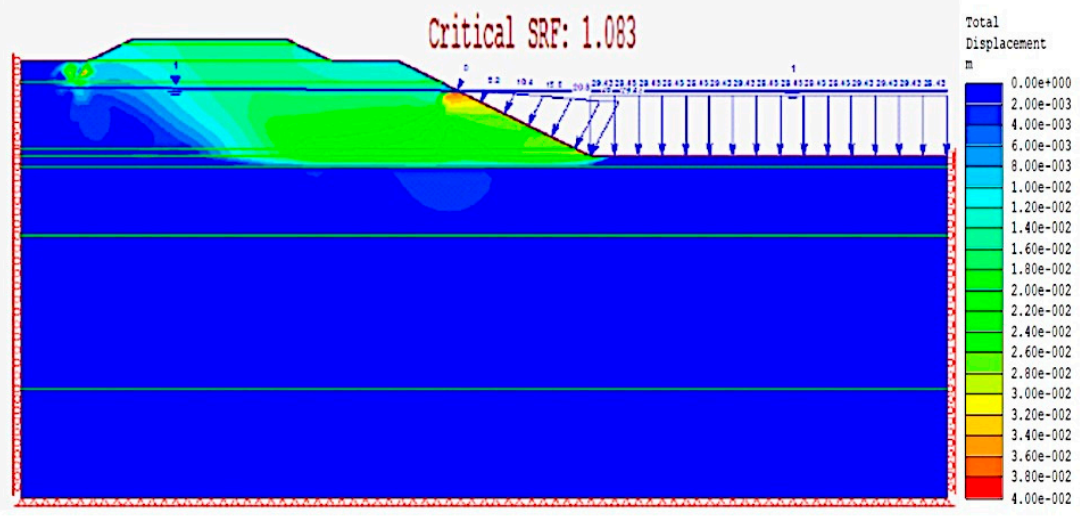

(a)

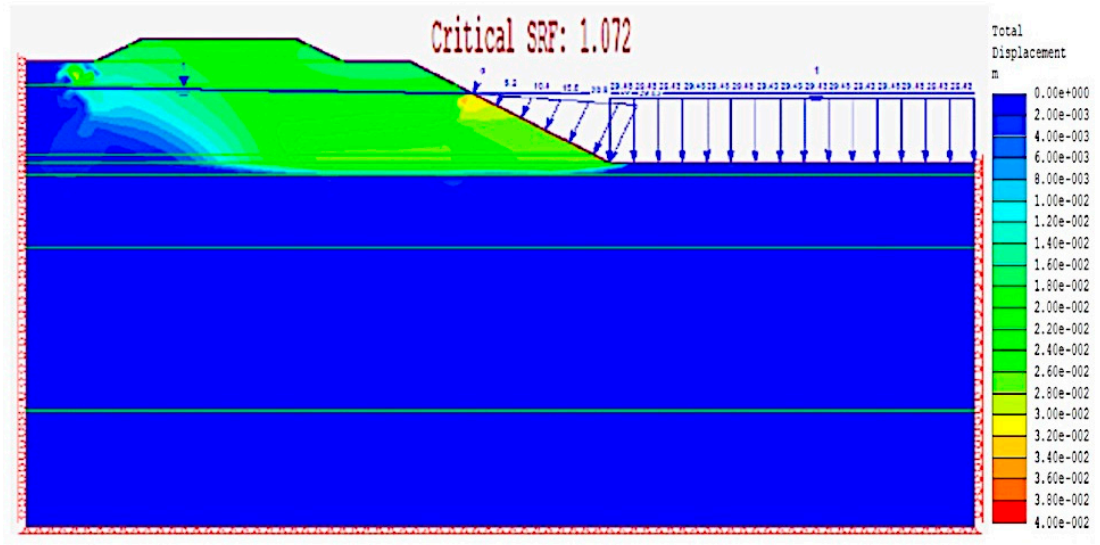

(b)

Figure 15. Colored contour shading of total displacement at SLR by (a) $26.70 \mathrm{~cm}$ and (b) $51.30 \mathrm{~cm}$.

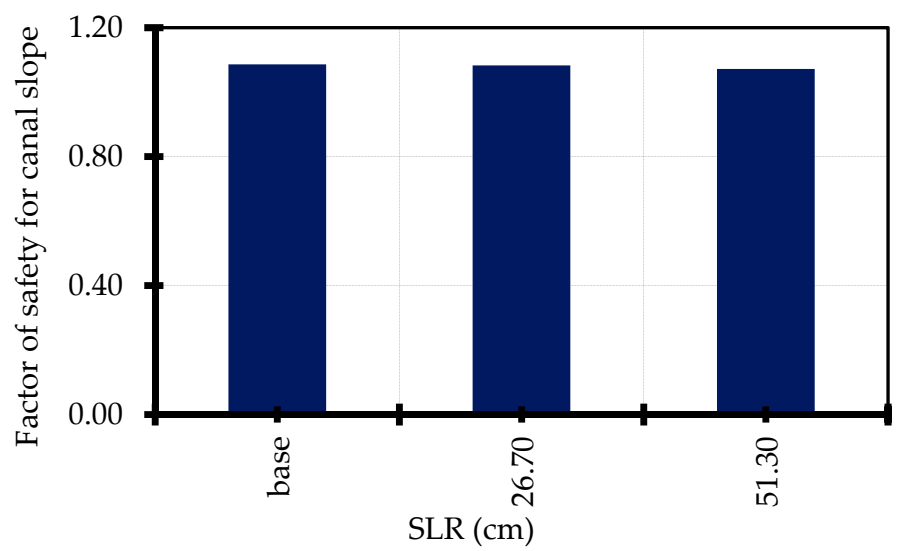

Figure 16. Canal factor of safety for rise in sea level by 26.70 and $51.30 \mathrm{~cm}$.

\subsection{Effect of Earthquake Intensity on Factor of Safety of Canal Slope}

The earthquake acceleration intensities $0.1 \mathrm{~g}$ and $0.2 \mathrm{~g}$ were studied. Figures 17 and 18 describe shear strain and total displacement distribution due to change the earthquake acceleration intensities to $0.1 \mathrm{~g}$ and $0.2 \mathrm{~g}$. The results indicated that the canal embankment slope safety factors reached 0.436 and 0.204 when the earthquake acceleration changed to $0.1 \mathrm{~g}$ and $0.2 \mathrm{~g}$ respectively. Moreover, the maximum shear strain increases with depth to reach the last layer of sand. Furthermore, the increase in earthquake acceleration leads to significant deformation increase. Figure 19 represents the relation between the decrease of canal slope FOS and the earthquake intensity increase. It is noticed that for 
earthquake intensities equal $0.1 \mathrm{~g}$ and $0.2 \mathrm{~g}$ the FOS decreases by $59.9 \%$ and $81.2 \%$ from the base case, respectively.

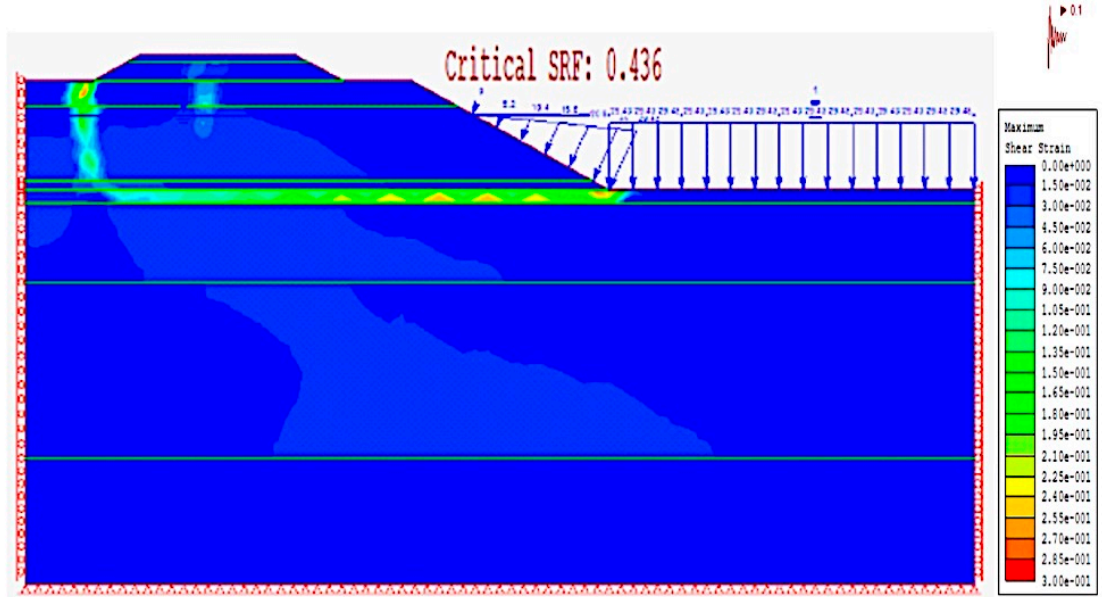

(a)

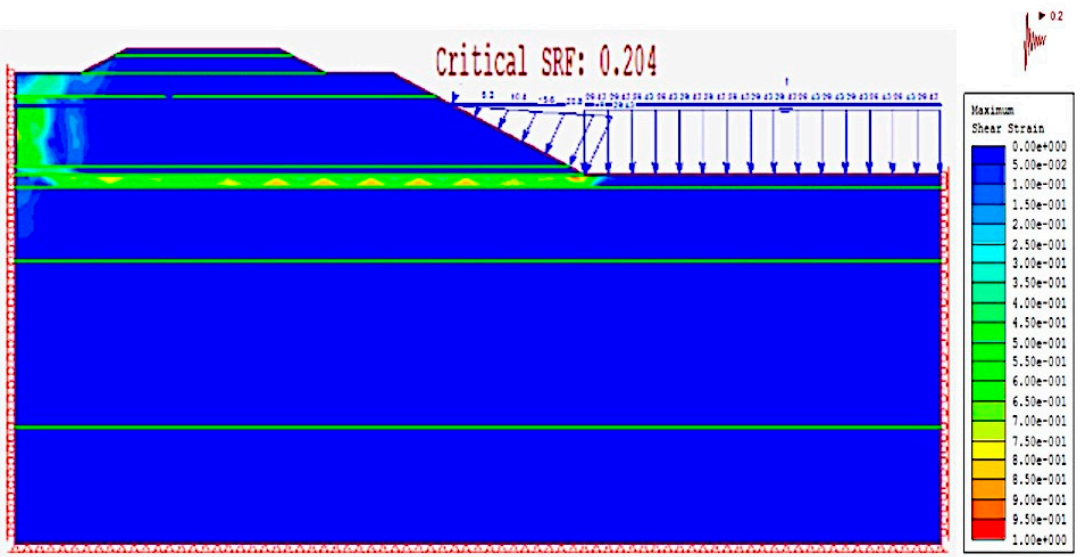

(b)

Figure 17. Colored contour shading of shear strain at earthquake acceleration changed by (a) $0.1 \mathrm{~g}$ and (b) $0.2 \mathrm{~g}$. 


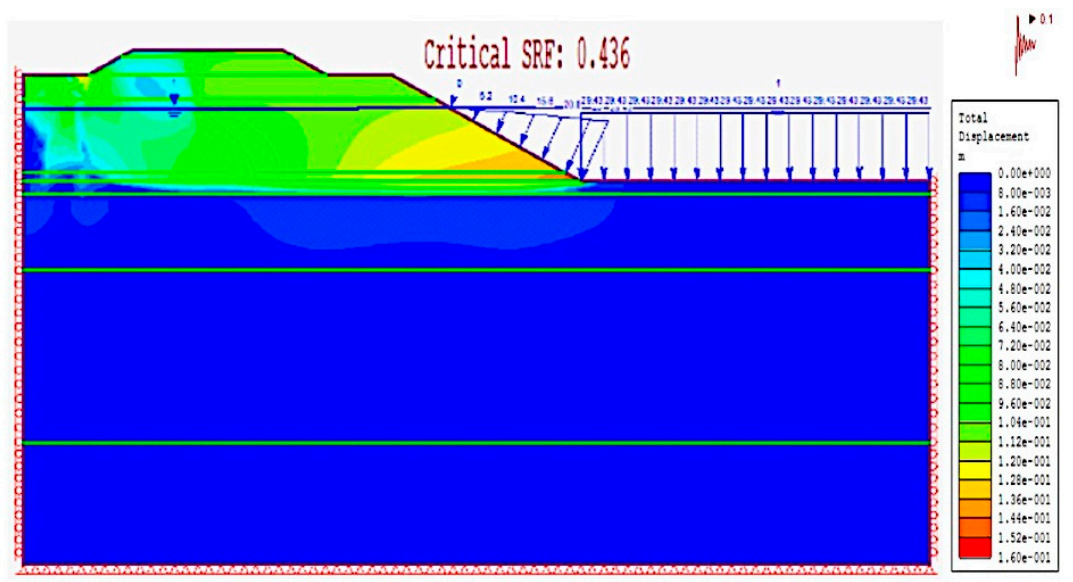

(a)

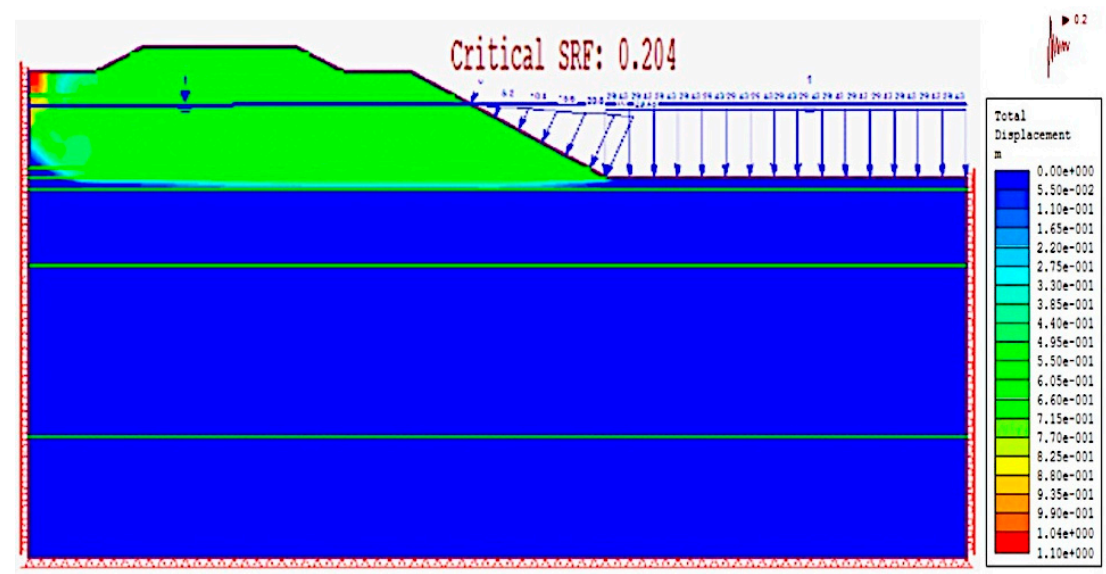

(b)

Figure 18. Colored contour shading of total displacement at earthquake acceleration changed by (a) $0.1 \mathrm{~g}$ and (b) $0.2 \mathrm{~g}$.

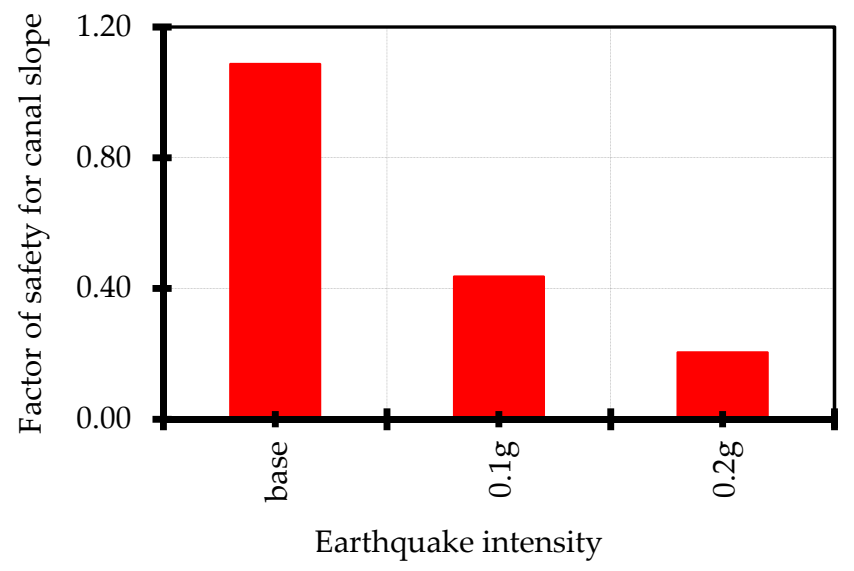

Figure 19. Canal factor of safety for earthquake intensity by $0.1 \mathrm{~g}$ and $0.2 \mathrm{~g}$.

\subsection{Effect of Combination Scenario on Factor of Safety of Canal Slope}

The following stage of the numerical modeling was carried out to study the effect of the combination of SLR by 26.70 and $51.30 \mathrm{~cm}$ with earthquake acceleration of $0.1 \mathrm{~g}$ and $0.2 \mathrm{~g}$. The results show that the 
slope factor of safety reached 0.42 and 0.405 when SLR was $26.70 \mathrm{~cm}$, while it reached 0.2 and 0.196 when SLR was $51.30 \mathrm{~cm}$ under earthquake acceleration of $0.1 \mathrm{~g}$ and $0.2 \mathrm{~g}$ respectively. The maximum shear strain distribution was studied. Moreover, the results of total displacement in the canal slope were presented, as shown in Tables 1 and 2. Figure 20 represents the effect of the combination of SLR and earthquake intensity on canal slope FOS. It is noticed that for SLR $26.70 \mathrm{~cm}$, the FOS decreases by $61.3 \%$ and $81.5 \%$ from the base case for earthquake intensities equal $0.1 \mathrm{~g}$ and $0.2 \mathrm{~g}$ respectively. Furthermore, for SLR $51.30 \mathrm{~cm}$, the decrease percentages reach $62.7 \%$ and $81.95 \%$ from the base case for earthquake intensities equal $0.1 \mathrm{~g}$ and $0.2 \mathrm{~g}$ respectively.

Table 1. Maximum total displacement for different scenarios.

\begin{tabular}{cccccc}
\hline Stage & Scenario & Description & $\begin{array}{c}\text { Factor of } \\
\text { Safety }\end{array}$ & $\begin{array}{c}\text { Maximum Total } \\
\text { Displacement }(\mathbf{m})\end{array}$ & $\begin{array}{c}\text { Total Displacement } \\
\text { at Toe }(\mathbf{m})\end{array}$ \\
\hline Base case & - & Current situation & 1.086 & 0.038 & 0.026 \\
SLR & 1 & SLR $26.70 \mathrm{~cm}$ & 1.083 & 0.040 & 0.030 \\
& 2 & SLR $51.30 \mathrm{~cm}$ & 1.072 & 0.040 & 0.024 \\
Earthquake Intensity & 3 & $\mathrm{a}_{\mathrm{h}} 0.1 \mathrm{~g}$ & 0.436 & 0.160 & 0.160 \\
& 4 & $\mathrm{a}_{\mathrm{h}} 0.2 \mathrm{~g}$ & 0.204 & 1.040 & 0.605 \\
SLR \& Earthquake & 5 & SLR $26.70 \mathrm{~cm}, \mathrm{a}_{\mathrm{h}} 0.1 \mathrm{~g}$ & 0.420 & 0.170 & 0.162 \\
& 6 & SLR $51.30 \mathrm{~cm}, \mathrm{a}_{\mathrm{h}} 0.1 \mathrm{~g}$ & 0.405 & 0.150 & 0.142 \\
& 7 & SLR $26.70 \mathrm{~cm}, \mathrm{a}_{\mathrm{h}} 0.2 \mathrm{~g}$ & 0.200 & 0.400 & 0.160 \\
& 8 & SLR $51.30 \mathrm{~cm}, \mathrm{a}_{\mathrm{h}} 0.2 \mathrm{~g}$ & 0.196 & 0.400 & 0.140 \\
\hline
\end{tabular}

Table 2. Maximum shear strain for different scenarios.

\begin{tabular}{cccccc}
\hline Stage & Scenario & Description & $\begin{array}{c}\text { Factor of } \\
\text { Safety }\end{array}$ & $\begin{array}{c}\text { Maximum } \\
\text { Shear Strain }\end{array}$ & $\begin{array}{c}\text { Shear Strain } \\
\text { at Toe }\end{array}$ \\
\hline Base case & - & Current situation & 1.086 & 0.16 & 0.008 \\
SLR & 1 & SLR $26.70 \mathrm{~cm}$ & 1.083 & 0.16 & 0.008 \\
& 2 & SLR $51.30 \mathrm{~cm}$ & 1.072 & 0.17 & 0.009 \\
Earthquake & 3 & $\mathrm{a}_{\mathrm{h}} 0.1 \mathrm{~g}$ & 0.436 & 0.29 & 0.015 \\
Intensity & 4 & $\mathrm{a}_{\mathrm{h}} 0.2 \mathrm{~g}$ & 0.204 & 0.95 & 0.050 \\
SLR \& Earthquake & 5 & SLR $26.70 \mathrm{~cm}, \mathrm{a}_{\mathrm{h}} 0.1 \mathrm{~g}$ & 0.420 & 0.30 & 0.015 \\
& 6 & SLR $51.30 \mathrm{~cm}, \mathrm{a}_{\mathrm{h}} 0.1 \mathrm{~g}$ & 0.405 & 0.30 & 0.015 \\
& 7 & SLR $26.70 \mathrm{~cm}, \mathrm{a}_{\mathrm{h}} 0.2 \mathrm{~g}$ & 0.200 & 0.40 & 0.040 \\
& 8 & SLR $51.30 \mathrm{~cm}, \mathrm{a}_{\mathrm{h}} 0.2 \mathrm{~g}$ & 0.196 & 0.40 & 0.040 \\
\hline
\end{tabular}

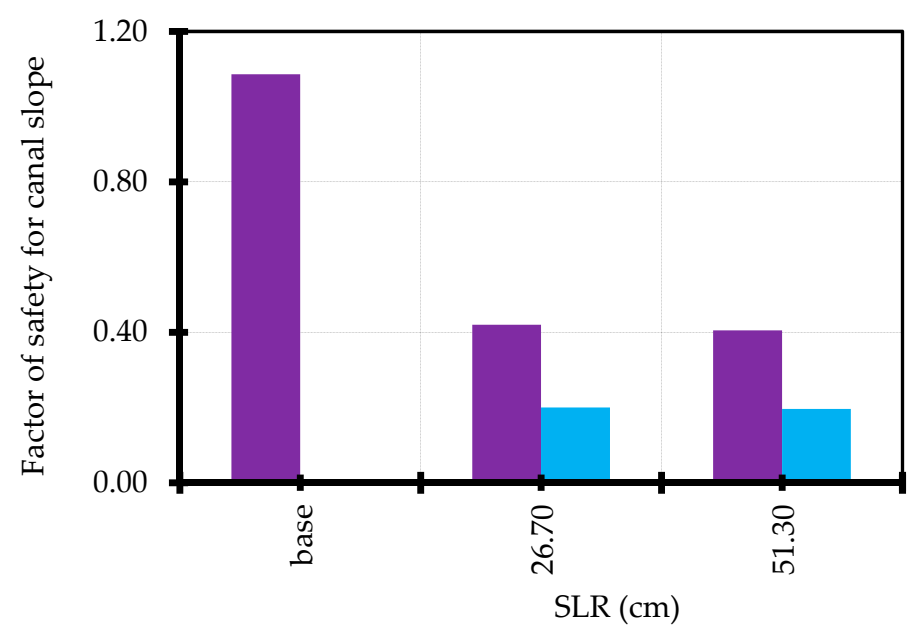

Earthquake intensity $(\mathrm{ah}=0.10 \mathrm{~g})$

Earthquake intensity $(\mathrm{ah}=0.20 \mathrm{~g})$

Figure 20. Canal factor of safety for combination of SLR and earthquake intensity.

\section{Conclusions}

The North Eastern part of Nile Delta aquifer is simulated using the finite difference code (MODFLOW). The groundwater flow under the effect of SLR is investigated to indicate its effect on 
slope stability of El-Salam Canal, Egypt. The present paper aims to investigate the stability of the canal slopes considering the climate changes through sea level rise and seismic actions. Moreover, the finite element program (Phase 2) is implemented, and FOS are calculated. The models are calibrated and verified through experimental work using permeability and seepage model. As a result of climate changes and sea level rise, the groundwater level raises at the project area, thus led to study two scenarios of SLR by $26.70 \mathrm{~cm}$ and $51.30 \mathrm{~cm}$. This action allows the flow of water towards the canal, and reduces the canal slopes stability. Inasmuch of this, the canal slope FOS decreases by about $0.3 \%$ and $1.3 \%$ respectively. Furthermore, earthquake probability of intensity equals $0.1 \mathrm{~g}$ and $0.2 \mathrm{~g}$ is studied, it causes a drop in FOS by about $60 \%$ and $81 \%$ respectively. Finally, it was concluded that the occurrence of earthquake even with small accelerations has a significant effect on the slope stability of El-Salam Canal.

Author Contributions: The authors contributed substantially to conception, data acquisition, analysis and interpretation of data. All authors participate in drafting the article or revising it critically; and give final approval of the version to be submitted. They are accountable for all aspects of the work in ensuring that the accuracy or integrity of any part of the work are appropriately investigated.

Funding: This research received no external funding.

Acknowledgments: The authors wished to express their sincere appreciation to the Department of Water and Water Structures Engineering, Faculty of Engineering, Zagazig University, for the instrument and software facilities. This work is thankful to be supported by project of the Ministry of Education of the Slovak Republic VEGA 1/0217/19 Research of Hybrid Blue and Green Infrastructure as Active Elements of a 'Sponge City and the project od Slovak Research and Development Agency APVV-18-0360 Active hybrid infrastructure towards to sponge city'.

Conflicts of Interest: The authors declare no conflict of interest.

\section{References}

1. Berilgen, M. Investigation of Stability of Slopes Under Drawdown Conditions. Comput. Geotech. 2007, 34, 81-91. [CrossRef]

2. Salem, T.; Hassan, K.; Mashhour, M.; Abu-Elella, A. Assessment of Slope Stability Using FEM. In Proceedings of the 7th International Conference on Civil and Architecture Engineering, ICCAE-7, Military Technical College, Cairo, Egypt, 21-23 November 2008; pp. 258-272.

3. Jebelli, J.; Meguid, M. Soil Stability Analysis in Irrigation Canals: A Case Study. J. Egypt. Geotech. Soc. 2013, $18,4153-4168$.

4. Harvey, N. Rates and Impacts of Global Sea-Level Change. In New Frontiers in Environmental Research; Glazer, M.P., Ed.; Nova Science Publishers: New York, NY, USA, 2006; Chapter 1.

5. Church, J.; White, N.; Aarup, T.; Wilson, W.; Woodworth, P.; Domingues, C.; Hunter, J.; Lambeck, K. Understanding Global Sea Levels: Past, Present and Future. Sustain. Sci. 2008, 3, 1-167. [CrossRef]

6. IPCC. Climate Change 1995: The Science of Climate Change Contribution of Working Group I to the Second Assessment Report of the Intergovernmental Panel on Climate Change; Houghton, J., Meira Filho, L., Callander, B., Harris, N., Kattenberg, A., Maskell, K., Eds.; Cambridge University Press: Cambridge, UK; New York, NY, USA, 1996; p. 572.

7. IPCC. Climate Change 2001: Impacts, Adaptations, and Vulnerability Contribution of Working Group II to the Third Assessment Report of the Intergovernmental Panel on Climate Change; Mc Carthy, J., Canziani, O., Leary, N., Dokken, D., White, K., Eds.; Cambridge University Press: Cambridge, UK; New York, NY, USA, 2001.

8. IPCC. An Assessment of the Intergovernmental Panel on Climate Change. In Proceedings of the Adopted Section by Section at IPCC Plenary XXVII, Valencia, Spain, 12-17 November 2007; IPCC: Geneva, Switzerland, 2007.

9. $\quad$ Legeais, J.F.; Ablain, M.; Zawadzki, L.; Zuo, H.; Johannessen, J.A.; Scharffenberg, M.G.; Fenoglio-Marc, L.; Fernandes, M.J.; Andersen, O.B.; Rudenko, S.; et al. An improved and homogeneous altimeter sea level record from the ESA Climate Change Initiative. Earth Syst. Sci. Data 2018, 10, 281-301. [CrossRef]

10. Leaven, M. Hydrogeological Study of the Nile Delta and Adjacent Desert Areas, Egypt, with Emphasis on Hydrochemistry and Isotope Hydrology. Master's Thesis, Free University, Amsterdam, The Netherlands, 1991. Also published by RIGW/IWACO as Technical note TN 77.01300-91-01.

11. Ball, J. Contribution to the Geology of Egypt; Egyptian Survey and Mines Department: Cairo, Egypt, 1939; pp. 1-308. 
12. RIGW. Hydrogeological Map of Nile Delta, Scale 1:500,000, 1st ed.; RIGW: El Kanater El Khairia, Nile Delta, Egypt, 1992.

13. Said, R. The Nile River: Geology, Hydrology, and Utilization; Pergamon Press: New York, NY, USA, $1993 ;$ p. 320.

14. Serag El Din, H. Geological, Hydrochemical and Hydrological Studies on the Nile Delta Quaternary Aquifer. Ph.D. Thesis, Faculty of Science, Mansoura University, Mansoura, Egypt, 1989.

15. Sherif, M.; Al-Rashed, M. Vertical and Horizontal Simulation of Seawater Intrusion in the Nile Delta Aquifer. In Proceedings of the 1st International Conference and Workshop on Saltwater Intrusion and Coastal Aquifers, Monitoring, Modelling, and Management, Essaouira, Morocco, 23-25 April 2001.

16. Sherif, M.M.; Sefelnasr, A.; Javadi, A. Incorporating the Concept of Equivalent Freshwater Head in Successive Horizontal Simulations of Seawater Intrusion in the Nile Delta Aquifer, Egypt. J. Hydrol. 2012, 186-198. [CrossRef]

17. Mabrouk, B.; Abd-Elhamid, H.; Badr, B.; Ralf, L. Adaptation to the Impact of Sea Level Rise in the Northeastern Nile Delta, Egypt. In Geophysical Research Abstracts; EGU2013-4042; EGU General Assembly: Munich, Germany, 2013.

18. Abd-Elaty, I.; Abd-Elhamid, H.; Fahmy, M.; Abdelaal, G. Study Climate Changes and its Impact on Ground water System in Nile Delta Aquifer. Egypt. Int. J. Eng. Sci. Technol. 2014, 17, 2061-2079.

19. Abd-Elaty, I.; Sallam, G.A.; Strafacec, S.; Scozzari, A. Effects of climate change on the design of subsurface drainage systems in coastal aquifers in arid/semi-arid regions: Case study of the Nile delta. Sci. Total Environ. J. 2019, 672, 283-295. [CrossRef] [PubMed]

20. Kramer, S.; Lindwall, N. Dimensionality and Directionality Effects in Newmark Sliding Block Analyses. J. Geotech. Geoenviron. Eng. 2004, 130, 303-315. [CrossRef]

21. Maula, B.H.; Zhang, L. Assessment of Embankment Factor Safety Using Two Commercially Available Programs in Slope Stability Analysis. Procedia Eng. 2011, 14, 559-566. [CrossRef]

22. Nadi, B.; Askari, F.; Farzaneh, O. Seismic Performance of Slopes in Pseudo-Static Designs with Different Safety Factors. Int. J. Sci. Technol. Trans. Civil Eng. 2014, 38, 465-483.

23. Hossain, M.; Haque, M.; Qasim, S.; Hoyos, L. Seismic Stability of Bioreactor Landfill with Decomposition-A Numerical Modeling. In Proceedings of the 4th International Conference on Earthquake Geotechnical Engineering, Thessaloniki, Greece, Balkans, 25-28 June 2007. Paper No. 1266.

24. Huang, S.; Lv, Y.; Peng, Y.; Zhang, L.; Xiu, L. Effect of Different Groundwater Levels on Seismic Dynamic Response and Failure Mode of Sandy Slope. PLoS ONE 2015, 10, e0142268. [CrossRef] [PubMed]

25. Abd-Elhamid, H.; Abd-Elaty, I.; Sherif, M. Evaluation of potential impact of Grand Ethiopian Renaissance Dam on Seawater Intrusion in the Nile Delta Aquifer. Int. J. Environ. Sci. Technol. 2019, 16, 2321-2332. [CrossRef]

26. EGSA (Egyptian General Survey and Mining). Topographical Maps Cover Nile Delta; EGSA: Cairo, Egypt, 1997.

27. MWRI. Adaptation to Climate Change in the Nile Delta through Integrated Coastal Zone Management; Ministry of Water Resources and Irrigation: Cairo, Egypt, 2013.

28. Emam, T.; Hydraulics, D. Operational Management System for El-Salam Canal. Inception Repor. 2000. Available online: file://C:/Users/MARTIN \{\}1/AppData/Local/Temp/Inception_Report.pdf (accessed on 10 November 2018).

29. Donia, N. Development of El-Salam Canal Automation System. J. Water Resour. Prot. 2012, 4, 597-604. [CrossRef]

30. MWRI. National Water Resources Plan for Egypt 2017. 2005. Available online: http://extwprlegs1.fao.org/ docs/pdf/egy147082.pdf (accessed on 10 November 2018).

31. Hafez, A. Investigation of El-Salam Canal Project in Northern Sinai, Egypt Phase-I: Environmental Baseline, Soil and Water Quality Studies. In Proceedings of the Ninth International Water Technology Conference, IWTC9 2005, Sharm El-Sheikh, Egypt, 17-20 March 2005.

32. Mohamed, A. Irrigation Water Quality Evaluation In El-Salam Canal Project. Int. J. Eng. Appl. Sci. $2012,3,1$.

33. McDonald, M.; Harbaugh, A. A Modular Three-Dimensional Finite-Difference Ground-Water Flow Model; USGS TWRI 93 Chapter 6-A1; U.S. Geological Survey: Reston, VA, USA, 1988. [CrossRef]

34. Griffiths, D.; Lane, P. Slope Stability Analysis by Finite Elements, Phase 2, Version 8.005. In Geotechnique; Rocscience Inc.: Ontario, ON, Canada, 2011; Volume 49, pp. 387-403.

35. Bishop, A. The Strength of Soils as Engineering Materials. In Sixth Rankine Lecture, Geotechnique; Rocscience Inc.: Ontario, ON, Canada, 1966; Volume 16, No. 2; pp. 89-130. 
36. Das, B. Advanced Soil Mechanics; Hemisphere Pub. Corp.: Washington, DC, USA; McGraw-Hill: New York, NY, USA, 1983.

37. Mohamed, A.A.; El-Hadidy, M.; Deif, A.; Abou Elenean, K. Seismic hazard studies in Egypt. NRIAG J. Astron. Geophys. 2012, 1, 119-140. [CrossRef]

38. Ambraseys, N.N.; Melvilie, C.P.; Adam, R.D. The Seismicity of Egypt, Arabia and the Red Sea a Historical Review; Cambridge University Press: Cambridge, UK, 1994; pp. 1-137.

39. Badawy, H.S.; Mourad, S.A. Observations from the 12 October 1992 Dahshour Earthquake in Egypt. Natl. Hazards 1994, 10, 261-274. [CrossRef]

40. Khater, M. Reconnaissance report on the Cairo, Egypt earthquake of October 12, 1992. NCEER Bull. 1993.

41. Badawy, A.; Korrat, I. Update earthquake risk assessment in Cairo, Egypt. J. Seismol. 2017, 21, 571-589. [CrossRef]

42. Al-Ashaal, A.; Abdel-Motaleb, A.; Haggag, H. Stabilizing Embankment Made of and Founded Over Weak Soil Using Piles: A Case History. Soil Mech. Found. J. Egypt. Geotech. Soc. 1998, 9, 10073-10094.

43. Badawy, A.; Korrat, I.; El-hadidy, M.; Gaber, H. Probabilistic earthquake hazard analysis for Cairo, Egypt. J. Seismol. 2016, 20, 449-461. [CrossRef]

44. Morsy, W.S. Environmental Management to Groundwater Resources for Nile Delta Region. Ph.D. Thesis, Faculty of Engineering, Cairo University, Cairo, Egypt, 2009.

45. Al-Quamhawy, S. Rehabilitation of Irrigation and Drainage Networks in Sharkia Irrigation Directorate. Master's Thesis, Faculty of Engineering, Zagazig University, Ash Sharqia Governorate, Egypt, 2016.

(C) 2019 by the authors. Licensee MDPI, Basel, Switzerland. This article is an open access article distributed under the terms and conditions of the Creative Commons Attribution (CC BY) license (http://creativecommons.org/licenses/by/4.0/). 